Article

\title{
Green Product Innovation and Firm Performance: Assessing the Moderating Effect of Novelty-Centered and Efficiency-Centered Business Model Design
}

\author{
Yuan Ma ${ }^{1, *}$, Qiyue Yin ${ }^{2}$, Yajun Pan ${ }^{1}$, Wei Cui ${ }^{1}$, Baogui Xin ${ }^{1}$ (i) and Ziqian Rao ${ }^{1}$ \\ 1 College of Economics and Management, Shandong University of Science and Technology, Qingdao 266590, \\ China; panyajun66@163.com (Y.P.); xiubin0708@sohu.com (W.C.); xin@tju.edu.cn (B.X.); \\ jacquelinerao@163.com (Z.R.) \\ 2 Department of Finance and Economics, Shandong University of Science and Technology, Jinan 250031, \\ China; yinqiyue0804@gmail.com \\ * Correspondence: may@sdust.edu.cn; Tel.: +86-0532-860-57574
}

Received: 22 April 2018; Accepted: 31 May 2018; Published: 2 June 2018

\begin{abstract}
Motivated by government policies and decision-makers' opportunity perception, many firms have invested in green product innovation. The effect of this type of innovation has been analyzed in extant literature thoroughly, but how to improve innovator's economic performance is still under-researched. When considering this research gap, the business model theory is used in this paper. An empirically based and testable framework is developed. Using survey data from 231 traditional manufacturing firms in China, these hypotheses are tested. The results show that novelty-centered and efficiency-centered business model design themes all play a moderating effect on the relationship between green product innovation and firm performance, while a fit between green product innovation and novelty-centered design theme is better for firm performance.
\end{abstract}

Keywords: green product innovation; business model; novelty-centered design theme; efficiency-centered design theme

\section{Introduction}

The idea that innovation can lead to economic growth and development has been widely accepted by academia and industry. But, the problem of how to achieve a win-win situation of economy and environment through innovation has not been noticed by researchers until 1990s. OECD predicts that by 2050, the global population will reach to 9 billion 200 million, with 2 billion 200 million new population [1]. Billions of people's necessities will consume more enormous natural resources, which will lead to the deteriorating natural environment and global climate change. The current way of innovation will certainly not support the global economic development in the coming decades. Fortunately, the political elites, entrepreneurs, environmentalists, and other people begin to explore this problem and realize the importance of green product innovation in solving sustainable development.

Most extant literature of green innovation, including green product, focuses on its effect on firm performance. To figure out this problem, scholars launch a large number of theoretical and empirical studies [2-9]. The environmental performance of green product is beyond doubt. Influenced by the research context and other factors, the relationship between green innovation and financial performance is quite different [4-13].

Motivated by government policies and decision-makers' opportunity perception, many firms in China have invested in green product innovation [12]. Numerous firms have regarded green product innovation as a crucial way to achieve long-term development [13-22]. However, these firms do not 
achieve expected innovation outcomes [23-25]. They are not only facing the lack of technology, but also challenges from the market. For example, Shanghai Food Wastes Processing Technology Co., Ltd. (Shanghai, China) has carried on the green innovation in the aspect of products by processing kitchen waste and converting it to the animal feed. Although technically, this innovation is successful, the company has encountered a kitchen garbage collection difficulties and other market problems in the actual operation. The main reason that influences the popularity of green products is not the lack of technology, but the numerous challenges from the market $[18,19]$. The uncertainty between the economic performance and green product innovation has reduced the interest of innovators to such projects, which hindered social sustainable development and economic transformation [20-23].

Although there are many researches on green innovation, and academia still lacks specific focus on green product innovation [24]. The discussion of issues, such as whether the green product innovation can create economic performance for firms and how to make it are insufficient. Being aware of the existing gap in current researches, the research question of this paper is how to create economic performance by green product innovation. Technology innovation is not only a technical activity, but also a commercial practice. Innovators need to gather diverse stakeholders, such as investors, suppliers, consumers, etc. [26-30]. Achieving economic success is the important symbol to measure the success of green product innovation [15]. For this reason, this article introduces the theory of business model design, discusses the role of two different design themes in the relationship between green product innovation and firm performance, and explores the more suitable design theme in this situation by comparison. The contributions of this article are as follows: (1) theoretically analyzed whether green product innovation can optimize firms' economic performance. Although there are many research achievements of green innovation and firm performance, most of them have not made a specific distinction between the types of innovation, our research focuses on green product innovation to make up for this deficiency; (2) Due to the need to take into consideration the unexpected events affecting this relationship, we explore the positive correlation between green product innovation and firm performance by analyzing how the interaction between green product innovation and business model design could lead to the improvement of firm performance. The conclusion of the study has opened up the operation idea for firms in order to improve the success rate of green product innovation.

This study is organized as follows. The relevant conceptions and hypotheses are introduced in Section 2. Samples, questionnaires, and variables are explained in Section 3, and the results are shown in Section 4. The implications of our findings are discussed in Section 5, and the limitations and future research are discussed in the last section.

\section{Hypothesis}

\subsection{Green Product Innovation and Firm Performance}

It is commonly accepted that green product innovation is that new or modified product aimed towards reducing environmental impact [3,7]. It includes the introduction and improvement in the product through the utilization of eco-friendly materials or recovered materials because this approach can reduce environmental impact in the input measures; it also includes product modifications that are aimed to reduce energy conservation, pollution prevention during products' usage [3,5,7]. Some researchers consider that the biggest problem affecting the environment is caused by the use and emissions of products [5]. A survey from McKinsey indicated that $60 \%$ of the interviewed CEOs believed that dealing with environmental change and exploring new market posses strategic implications to long-term flourishing of firms [31]. Environmental pressure and attraction from market motivate green product innovation, which has become a new trend of firm innovation [15]. Due to the tremendous uncertainty and high requirement on infrastructure and consuming habits, the radical innovation does not take up a large portion in industry at present [15]. Thus, this paper mainly focuses on the incremental innovation of green product. 
In the existing research, many scholars have emphasized the importance of green innovation to firms. The ability of green innovation helps to reduce the cost of firm and to improve firm's competitiveness [32,33]. Firms will be better able to face resource depletion and energy price fluctuations by carrying out green innovation [34]. Meanwhile, with the gradual improvement of consumers' environmental awareness, green product innovation could optimize corporate image to improve competitiveness [35]. Lanoie \& Ambec further summarizes the ways of green product innovation to improve firm performance, including better access to certain markets and differentiating product [32].

By summarizing the existing research, we may see that the two types green product innovation mentioned in this article can improve the economic performance of firms by the following ways:

(1) By using recycled materials to manufacture products could reduce cost and increase revenue. When compared to the initial input of raw materials, recycled materials are relatively inexpensive. For example, recycled paper costs lower than the original pulp paper. Many countries encourage firms to reuse wasted materials, and this kind of product innovation will be subsidized by the State, so the firm's income will be increased [32]. In addition, the use of recycled materials can also help firms to develop markets. For example, the public sectors in the United States and the United Kingdom (UK) have special requirements of raw materials in the public procurement process, such as the reuse of recycled materials and the sustainability of raw materials [24,36].

(2) Changing product design to reduce the energy/resources consumption and the environmental impact in the use of products could increase the firm's market share and sales revenue. Private firms have taken steps to "green" their supply chains. Green suppliers will be rewarded more. For example, Body Shop, Wal-Mart and other companies have developed a rigorous evaluation system for suppliers, they also implement an integral incentive program to encourage merchandise buyers to purchase green products. Driven by these socially responsible retailers, the market share of green product manufacturers is expanded. In addition, green products are also conducive to the innovation of firms to implement the differentiation strategy in order to develop a niche market. Sales data in the European market shows that sales of products with green labels have grown rapidly in the past 10 years [7]. Existing studies have revealed that firms can capture market and increase incomes through developing environmental-friendly products $[7,34,35]$.

Therefore, this article proposes the following hypothesis:

Hypothesis 1. Green product innovation positively influences firm performance.

\subsection{Effect of Business Model Design on Firm Performance}

Any firm has its own boundary, it only occupies a part of the value network. Along with the gradual refinement of the social division of labor, the other relevant upstream and downstream activities could only rely on trading partners. In order to achieve value creation and value acquisition, firms should not only complete their own businesses, but also persuade potential partners to participate in its value creation. In this context, many scholars started launching studies of business models.

Business model is portrayed as a structural template that describes the transactions between focus firms and external organizations in the production factor market and the product factor market [37]. It transcends the boundaries of focus firms and it consists of a series of interdependent activity systems [38]. When designing this activity system, the firm needs to consider two aspects, design elements and design themes. Design elements describe the architecture of the business model and the main design elements include value proposition, partnership, cost structure, income model, etc. [37-39]. Design themes describe the holistic gestalt of firms' business models, which facilitate business models' conceptualization [38]. Efficiency-centered and novelty-centered design themes are often mentioned in extant literature [37,40]. Efficiency-centered design theme focuses on transaction efficiency and transaction cost as the business model got involved; novelty-centered design theme concentrates on introducing new transaction method or connecting with new transaction partners. Although the two 
business model themes have different emphases, they are not mutually exclusive and a firm could adopt two themes at the same time.

In today's dynamic business environment, business models are considered to be an important tool for firms to improve their performances and obtain competitive advantages [38,41]. For example, Mitchell and Coles pointed out that the effective business model could help firms to take the lead in acquiring new customers, so as to help firms obtain the first-mover advantage [42]. Zott and Amit pointed out that not only firm's strategy, but also business model design can bring in a competitive advantage [38]. Brettel and other people discovered that the efficiency-centered and novel-centered design themes both impact firm performance significantly [43]. Zott \& Amit finds that the fit between business model and competition strategy has significantly positive effects on firm profitability [37].

Under the environment of green product innovation, the design of efficiency business model is beneficial to firm performance. It is because, when comparing to ordinary products, green products have characteristics of smaller environmental hazards. It is difficult for ordinary consumers to identify these environmental attributes of green products, product developers need to use efficient information systems to deliver product information in order to reduce the barriers in the transaction. In response to this information transmission difficulties, many green product manufacturers have applied for green product certification. In addition, in order to obtain other incomes, such as government subsidy, green product innovators need to actively disclose environmental information to obtain the approval of government and financial institutions. The novelty business model is also important. Through the novel business model design, focal firms could gather external organizations and social capitals that did not focus on environmental problems, and form the ecological circle that meets the firm development needs. Thus, we posit that:

Hypothesis 2a. Novelty-centered business model design positively moderates firm performance; Hypothesis $\mathbf{2 b}$. Efficiency-centered business model design positively moderates firm performance.

The conceptual framework in this paper is shown in Figure 1.

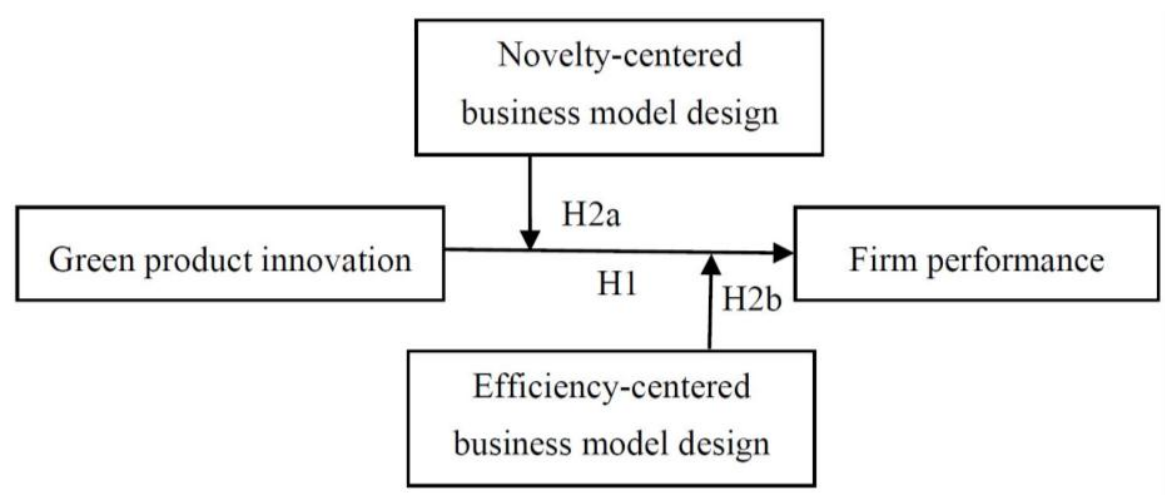

Figure 1. Conceptual framework.

\section{Research Design}

\subsection{Sample and Data Collection}

The sample firms in this paper are chosen from papermaking, food, home appliances, and other traditional manufacturing industries. The respondents in our survey are the middle and upper level managers who are familiar with their firms operation. The design of questionnaire is mainly based on the existing mature scales, and a Chinese-English back-translation is performed on the related foreign scales. At first, a structured and deep interview is made to the senior managers from three firms to ensure that the expression of the questionnaire is in line with the actual situation of the firm. According to the feedback from the managers, one professor and two postgraduates are invited to assess and 
modify the appropriateness of the items in the questionnaire. Then, the students of the MBA class at the author's university are invited to evaluate the questionnaire and are required to give their opinions on the conformity of the content and the readability of the questionnaire. Finally, we get the initial questionnaire. According to the sample data of the pre-survey, the scales are revised through reliability analysis and confirmatory factor analysis. On this basis, we form the formal questionnaire and then conduct the survey. In addition, according to the recommendations of literature, this research adopts some questionnaire design measures, such as guaranteeing anonymity, ensuring that there is no fixed answer, trying to use clear and explicit terms, using reverse language to break the stereotyped thinking pattern, as well as randomly adjusting item order and other methods to reduce potential common method bias [44]. Questionnaires are released from November 2017 to January 2018, a total of 800 questionnaires are distributed and 276 copies are recovered, except for the 46 invalid questionnaires, we finally get 231 valid questionnaires.

\subsection{Measurement}

\subsubsection{Independent Variables}

Community Innovation Survey (CIS) is used frequently in the innovation research. It has proved to be a valid and reliable tool to understand innovation and is widespread in the empirical literature. CIS lists nine issues about green innovation, including modifications to improve the environmental impact of raw materials, manufacturing processes, and finished products, etc. The existing studies have selected some or all of them, according to their respective needs $[11,20,28]$. Based on our analysis of green product innovation and the Community Innovation Survey in Europe, we designed the green product innovation scale, which mainly considers two aspects: the environmental influence of the finished product and the environmental influence of the input material. It specifically includes five items, "product design modifications aimed to reduce energy use at product's use; to reduce air, water, noise at product's use; to improve after-use recycling; to use less impacting raw materials; to substitute traditional materials with recycled ones".

Referring to the researches of Zott \& Amit [37], Brettel et al. [43], novelty-centered business model scale is designed from five aspects, such as new transaction partner, new transaction model, and so on; and, efficiency-centered business model scale is designed from five perspectives, such as simplifying transaction model, sharing transaction information, and so on.

\subsubsection{Dependent Variable}

Referring to the researches of Zott \& Amit [37], Brettel et al. [43], firm performance scale is designed from four perspectives, such as market share, customer satisfaction, and so on.

All of the scales adopt five-Likert Scale ( $1=$ strongly disagree, $5=$ strongly agree $)$ and the items are displayed in Appendix A.

\subsection{Control Variables}

After studying related literature $[9,15,39,43]$, this paper sets firm age, firm size, property nature, market size, and degree of competition as control variables. Among them, firm age takes age's logarithm, the size of the firm takes the number of employees' logarithm, and the property nature is set as a dummy variable (non-state owned $=0$, state owned $=1$ ). Market size is measured with a question, "the market size of existing products is very large" and the degree of competition is measured by a reverse question of "the industry of our firm has just arisen, so the competition is relatively small". These two control variables are measured by five-Likert scale. 


\section{Empirical Results}

\subsection{Descriptive Statistics of Variables}

The mean value, standard deviation, and correlation coefficients of the main variables are displayed in Table 1.

Table 1. Descriptive statistics and correlation coefficients of variables.

\begin{tabular}{|c|c|c|c|c|c|c|c|c|c|c|}
\hline & Mean & S.D. & 1 & 2 & 3 & 4 & 5 & 6 & 7 & 8 \\
\hline 1 & 1.110 & 0.446 & 1 & & & & & & & \\
\hline 2 & 3.158 & 0.932 & $0.616^{* *}$ & 1 & & & & & & \\
\hline 3 & 0.390 & 0.490 & -0.029 & $0.178 * *$ & 1 & & & & & \\
\hline 4 & 3.770 & 0.880 & 0.090 & $0.363 * *$ & 0.087 & 1 & & & & \\
\hline 5 & 4.130 & 0.710 & 0.019 & $0.168 * *$ & $0.149 *$ & $0.501 * *$ & 1 & & & \\
\hline 6 & 3.664 & 0.601 & 0.063 & $0.256^{* *}$ & 0.032 & $0.513 * *$ & $0.421^{* *}$ & 1 & & \\
\hline 7 & 3.691 & 0.621 & -0.033 & $0.182 * *$ & $-0.157^{*}$ & $0.486^{* *}$ & $0.524 * *$ & $0.453^{* *}$ & 1 & \\
\hline 8 & 3.663 & 0.593 & $-0.192 * *$ & 0.052 & $-0.137^{*}$ & $0.468 * *$ & $0.517^{* *}$ & $0.440^{* *}$ & $0.646^{* *}$ & \\
\hline 9 & 3.720 & 0.554 & -0.040 & $0.102 *$ & -0.087 & $0.518^{* *}$ & $0.475^{* *}$ & 0.430 ** & $0.519 * *$ & 0.526 ** \\
\hline
\end{tabular}

Based on the table above, we can see that there are moderate correlations between the main variables in this paper, which preliminarily validate the hypothesis in this research.

\subsection{Reliability and Validity}

Cronbach's $\alpha$ coefficient is used to test internal consistency reliability. These coefficients of the four scales are all above 0.8 , indicating that they have good reliability [45]. The design of the questionnaire is based on previous researches, and a proper modification is made under the advice of management experts. Therefore, the measurement scale of this paper has rather good content validity. Scale construct validity check is mainly carried out through confirmatory factor analysis. The fitting index shows that the fitting degree of the model is good $(\mathrm{GFI}=0.928$, AGFI $=0.912$, RMSEA $=0.042$ ).

\subsection{Results Analysis}

In order to validate the hypothesis that is mentioned in the paper, we adopt the multivariate regression technique, and the specific results are shown in Table 2. Model (1) reflects the impact of controlled variables on firm performance. We can see that non-state owned firms have better firm performance than state owned firms; the performance of the firms with large market capacity are relatively good, and the performance of the firms in high market competition are relatively good.

The independent variable green product innovation is added to model (2), and the result indicates that its effect on firm performance is positive $(\beta=0.178, P<0.01)$. Hypothesis H1 passes the significance test.

Models (3) and (4) are used to test Hypothesis 2a and models (5) and (6) to test Hypothesis $2 \mathrm{~b}$. In these models, we centralize the independent variables to reduce multicollinearity [45]. The independent variables of model (3) are green product innovation and novelty-centered design theme. On this basis, the interaction of the two is added to model (4). By comparing the results of these two models, we can see that the coefficient of the interaction is significant $(\beta=0.177, P<0.05)$; moreover, the adjusted $\mathrm{R}^{2}$ of model (4) is also higher than that of model (3), indicating that novelty-centered design theme plays a moderating role, which supports Hypothesis 2a. The independent variables of model (5) are green product innovation and efficiency-centered design theme, on this basis, the interaction of the two is added to model (6). When comparing the results of model (5) and model (6), we can see that the influence of the interaction to firm performance is positive and significant ( $\beta$ 
$=0.175, P<0.05$ ), and the adjusted $\mathrm{R}^{2}$ of model (6) is higher than that of model (5), indicating that efficiency-centered design theme also plays a moderating role. So Hypothesis $2 \mathrm{~b}$ is confirmed.

Table 2. Regression results.

\begin{tabular}{|c|c|c|c|c|c|c|c|}
\hline \multirow{2}{*}{ Variables } & (1) & (2) & (3) & (4) & (5) & (6) & (7) \\
\hline & $\beta$ & $\beta$ & $\beta$ & $\beta$ & $\beta$ & $\beta$ & $\beta$ \\
\hline Property & $-0.167^{* * *}$ & $-0.161^{* *}$ & $-0.103 *$ & $-0.078^{*}$ & $-0.109 * * *$ & $-0.104^{* *}$ & $-0.110^{* *}$ \\
\hline Firm age & -0.078 & -0.099 & -0.054 & -0.039 & 0.002 & 0.031 & -0.056 \\
\hline Firm size & -0.013 & -0.015 & -0.054 & -0.063 & -0.034 & -0.027 & -0.010 \\
\hline Market size & $0.390^{* * *}$ & $0.321^{* * *}$ & $0.284^{* * *}$ & $0.286^{* * *}$ & $0.163^{* * *}$ & $0.272 * * *$ & $0.241^{* * *}$ \\
\hline Competition & $0.308^{* * *}$ & $0.267^{* * *}$ & $0.190 * * *$ & $0.177^{* * *}$ & $0.125^{* * *}$ & $0.200^{* * *}$ & $0.208^{* * *}$ \\
\hline GPI & & $0.178^{* * *}$ & $0.134 * *$ & $0.132 * *$ & $0.143^{* * *}$ & $0.113 * *$ & $0.105^{* *}$ \\
\hline NBM & & & $0.213^{* * *}$ & $0.220 * * *$ & & & $0.162 * *$ \\
\hline EBM & & & & & $0.168^{* *}$ & $0.135^{* * *}$ & 0.130 \\
\hline GPI*NBM & & & & $0.177^{* *}$ & & & $0.102 * *$ \\
\hline GPI*EBM & & & & & & $0.075^{* *}$ & 0.021 \\
\hline$R^{2}$ & 0.364 & 0.386 & 0.411 & 0.426 & 0.421 & 0.434 & 0.457 \\
\hline Adjust $R^{2}$ & 0.352 & 0.372 & 0.395 & 0.408 & 0.406 & 0.412 & 0.433 \\
\hline $\mathrm{F}$ & $29.359 * * *$ & $31.732 * * *$ & $25.324^{* * *}$ & $25.562^{* * *}$ & $27.952^{* * *}$ & $28.537 * * *$ & $29.194^{* * *}$ \\
\hline
\end{tabular}

We further compared the two moderating effects through model (7). All of the independent variables and the interactions are put to model (7). The moderating effect that was played by novelty-centered design theme is still significant $(\beta=0.102, P<0.05)$, leading to a result that the moderating effect played by novelty-centered design theme is stronger than that of efficiency-centered.

The VIF values of these models are smaller than 2 , showing that multicollinearity problem is not serious. White's test result shows that heteroscedasticity is also not serious.

To further demonstrate the difference between these two moderating effects, plotting technique is used [46]. The results are presented, respectively, in Figures 2 and 3.

By comparing the moderating effects of these two design themes, we can find that novelty-centered theme has a better moderating effect. The plots of green product innovation on firm performance reveal that the slope of the regression line is larger for higher level of novelty (see Figure 2). By contrast, although the performance of green product innovation for a high level of efficiency is better than that of low level, the slope of the regression line is smaller (see Figure 3). A fit between green product innovation and novelty-centered design theme is more helpful to enhance firm performance.

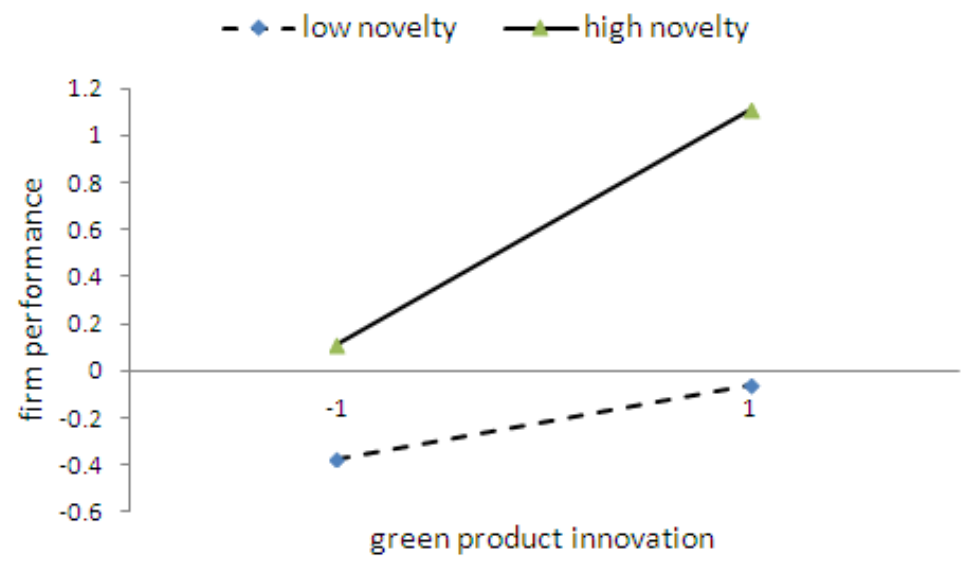

Figure 2. The moderating effect of novelty-centered design theme. 


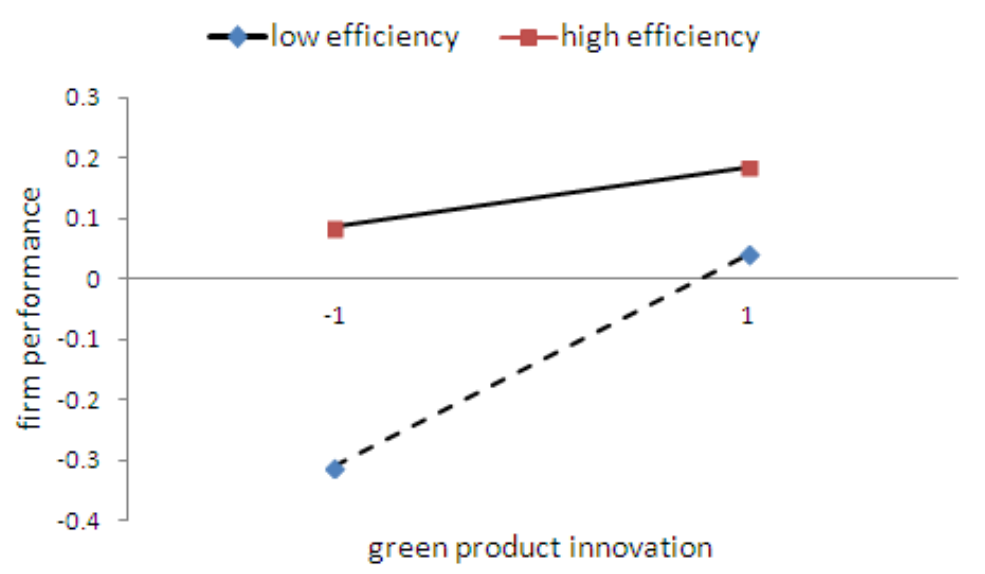

Figure 3. The moderating effect of efficiency-centered design theme.

\subsection{Discussion}

Efficiency-centered and novelty-center design themes both play moderating roles in the green product innovation-firm performance relationship. Although Zott \& Amit's research has found that the fit between efficiency-centered design theme and product market strategy does not have an obvious effect on firm performance, our research finds that, in the context of green product innovation, it is conducive to the market performance, which because, different from traditional products, green products have the inexplicit characteristic of little environment harm [37]. It is difficult for common consumers to identify this environmental attribute, therefore, product innovators need to use an efficient information system to transfer product information to consumers, so as to reduce obstacles in the market.

By comparing the moderating effects of the two design themes, we find that the novelty-centered theme has a better moderating effect. As we have mentioned in Section 2.1, there are two types of green product innovation, one is innovations as those that are related to energy conservation, pollution prevention during products' usage, such as phosphate-free detergents and electric cars; the other is the introduction and improvement in the product through the utilization of eco-friendly or recovered materials, such as recycled paper $[3,5,7]$.

For the first type, due to the limit of consumers' professional skills and lifestyles, as well as other factors, it is difficult for the green product innovators to be accepted by market at the early stage of market launching [47]. Although many studies have considered that customers are willing to pay higher prices for environmental attributes of green products, there is still a divergence in practice. Most consumers will ask such question: "what benefits can I get from using this kind of green product?" [48]. The survey from Green Gauge Report also shows that the reason why consumers are not willing to buy green products is that they think green products are expensive and having poor performance, which are not worth buying [49]. Consumers are only interested in the environmental attributes that are closely related to their personal interests. Overemphasizing the green performance of products without considering consumer preferences is the reason why many green products do not sell as well as the producer expects, such as the GM's EV-1 electric car [50]. This requires firms to find ways to satisfy consumers' interests and needs, instead of just emphasizing the environmental attributes of the green products [51,52]. In order to succeed in occupying the niche market, green product innovators need to emphasize the non-green value, such as convenience, identity and status symbols, health, and safety during product's commercialization [48]. These practical problems need firms to make big changes in the market [15]. In this case, novelty-centered design theme will be more helpful.

For the second type, it requires innovators to introduce new material suppliers into their operations and increase transaction partners in the existing business model. At the same time, 
in order to stimulate the participation of new material suppliers, firms need to design more incentive transaction mechanisms.

Through the comparison of two firms, we can see more clearly what role the novelty business model theme plays. Recycling Bank, which was founded by Patrick Fitzgerald and Ron Gonen in 2002 , is a firm that recycles used materials. This firm provides each family complimentary with a dedicated recycling bucket of renewable resources that is equipped with RFID tags to meter and acquire renewable resources from emitters regularly. The recycling bank will pay $\$ 5$ for each of the 10 pounds of renewable wastes; the money will be transferred to a bank card, which is specifically opened for cooperative families. Then the family could spend the money in any of the retailers that participate in the program and also have discounts. Retailers make profits from the businesses and then pay $30 \%$ of their profits to the recycling bank. The business model of the recycling bank has shown novelty in terms of cost, income, and partnership, and it has achieved great success. In stark contrast, Shanghai Food Wastes Processing Technology Co., Ltd., which is mentioned in the first part of this article, has similar businesses to the recycling bank, such as collecting garbage from restaurants and canteens and process them into animal feed. In order to reduce the kitchen wastes, Shanghai Municipal Government has introduced a management method of kitchen wastes, requiring payments for the emission of food wastes. In this context, Shanghai Food Wastes Processing Company developed the corresponding technology and started the market operation. Although there are government subsidies and regulatory supports, a considerable number of restaurants and canteens do not want to standardize the kitchen wastes due to the high costs of law enforcement. Therefore, Shanghai Food Wastes Processing Company suffered from the obstacles of the renewable resources recycle. Although they have adopted many methods to improve transaction efficiency, they are still lacking of responses from renewable resource emitters. Through the comparison of these two cases, we can see that the ecological circle of green product innovators has not been completely established in the early period of the transformation from traditional development to sustainable development, and the novel business model helps to gather all of the participants and help firms to form the ecological circle.

Although the design theme of the efficiency business model is also beneficial to the improvement of firm performance, novelty-centered design theme is more important when compared to the main problems that are faced by green product innovation. At the beginning of the transformation from traditional development to the sustainable development, the ecological environment of green product innovators has not been completely established, so firms have more needs of the novel business model.

\section{Conclusions and Implications}

\subsection{Conclusions}

This paper analyzes the role of two business model design themes in the relationship between green product innovation and firm performance. The empirical results show that both novelty and efficiency design themes play moderating roles, and the effect of novelty design theme is stronger.

\subsection{Implications}

Extant studies propose that these two design themes are not mutually exclusive, firms can hold different themes of business models at the same time. But, adopting two business models may simultaneously lead to the unbalanced resource allocation [53]. Our research finds that in the context of green product innovation, adopting novelty-centered design theme is more beneficial to the improvement of firm performance. Therefore, when considering the limited resources, firms can put more emphasis on the market development and the design of transaction mechanism.

Business model is an important source of firm's competitiveness. Proper business model design can increase firm's profits and reduce costs, which is an important way for firms to make profits. The environmental disruption that is caused by the rapid economic development has become a global problem. Although the desire for green development is becoming more and more intense in human 
society, the success rate of green projects in the market is still low [54,55]. When combined with the conclusions in this article, some implications can be given to firms' decision-makers and managers.

Gaining recognition in the marketplace and achieving economic performance are the sign of innovation success. Being accepted by consumers is the only way for green products to replace traditional products and to meet the consumer utility and environmental improvement at the same time. Therefore, the proactive green product innovators should not only focus on the development of products in the laboratory, but also think about how to gather all kinds of resources that are needed for product innovation, especially green raw material suppliers and green product consumers. The mindset that is formed by the traditional development model and the traditional commercial ecological environment obstruct the commercialization of green products. In the early stage of the transformation from the traditional development mode to the sustainable development mode, the Government provides some auxiliary measures to encourage firms to innovate, but finally, the firms have to operate independently, so firm managers should form the ecological environment for their green products through business model design as soon as possible. The environmental value of the green product will not be released if any parts on the value creation chain get lost. The sustainable development of human society depends on the change of the thinking mode of manufacturers, consumers, and other aspects, and the innovators should not only rely on the government's calls or regulations, but also pay attention to the active participation of all parties, exert initiative to explore new business model, and create an ecological environment, which is suitable for green product innovation.

Successful innovation firms could play an exemplary role in this respect. Firm managers could widen ideas through case studies, find niche markets through novel market positioning, and aggregate resources and develop markets through cross-border collaborations with both upstream and downstream, such as the collaboration between green product developers and retailers. More importantly, it encourages all parties to participate through a new way of value distribution.

The green feature of a product is often a hidden attribute that cannot be perceived by clients even after the purchase. It is insufficient for green product innovators to provide scientific solutions on environmental problems. A novelty business model should be considered in order to get closeness to customers. In addition to actively applying for Eco-label, firms also need to improve pricing methods to attract customers. For example, on a reasonably priced basis, a firm that sells green electric vehicles (or hybrids) can promise to provide complimentary charge or refuel within a predetermined mileage. This could switch the inexplicit environmental characteristics to the cost of use, which customers could feel.

By carrying out fantastic ideas in the design of business model, we could get the chance to aggregate all types of stakeholders that are needed in green product innovation, form the ecological environment of innovation firms, and complete the transformation of value creation to value acquisition. We believe that through the continuous attempt and effort of green innovation firms, green products will gradually replace the traditional goods, then reduce the burden of the earth, and promote sustainable human development.

\section{Limitations and Future Research}

This paper preliminarily discusses the profit channel of green product innovation, and it proposes that the novelty-centered design theme is more beneficial to the improvement of firm performance. In addition to the two design themes that we mentioned in this article, other themes, such as lock-in and complementarities, are also beneficial to firm performance. In the absence of early theoretical basis and measure scales, we have not considered these two themes yet. In the future research, scholars can focus on the question of how to profit from green product innovation and launch thorough discussions from the perspective of business model design elements.

Author Contributions: Y.M. (Yuan Ma) designed the research and wrote the paper; Q.Y. (Qiyue Yin) collected data and revised the paper; Y.P. (Yajun Pan) helped in data acquisition and analyzed the data; W.C. (Wei Cui) and B.X. (Baogui Xin) supervised the study; Z.R. (Ziqian Rao) reviewed the paper. 
Funding: This research was funded by Shandong Social Science Planning Foundation grant number [No. 17CGLJ21].

Acknowledgments: We would like to express our heartfelt thanks to the anonymous reviewers. It is because of their dedication and professionalism that this paper could finally be presented.

Conflicts of Interest: The authors declare no conflict of interest.

\section{Appendix A. Survey Items}

\begin{tabular}{|c|c|}
\hline Variable & Items \\
\hline \multicolumn{2}{|c|}{$\begin{array}{l}\text { Please rate the level of your firm's involvement in each of the following practices during the past } 3 \text { years. } \\
(1=\text { very low; } 5=\text { very high) }\end{array}$} \\
\hline \multirow{5}{*}{$\begin{array}{l}\text { Green product } \\
\text { innovation }\end{array}$} & A1 We try to modify the product design to reduce energy use at product's use. \\
\hline & A2 The wastes that are discharged during product's use are irrelevant to us. (reverse) \\
\hline & A3 We try to modify the product design to improve after-use recycling. \\
\hline & A4 We try to modify the product design to use less impacting raw materials. \\
\hline & $\begin{array}{l}\text { A5 We try to modify the product design to substitute traditional materials with } \\
\text { recycled ones }\end{array}$ \\
\hline \multirow{5}{*}{$\begin{array}{l}\text { Novelty business } \\
\text { model }\end{array}$} & B1 We can provide value-added services outside the products for our customers. \\
\hline & B2 We often introduce new trading partners. \\
\hline & $\begin{array}{l}\text { B3 In order to attract customers, suppliers and other trading partners to join, we } \\
\text { designed new incentive methods. }\end{array}$ \\
\hline & $\begin{array}{l}\text { B4 Designed new transaction methods for transaction partners such as customers, } \\
\text { suppliers, etc. }\end{array}$ \\
\hline & B5 Compared with our main competitors, our business model is novel. \\
\hline \multirow{5}{*}{$\begin{array}{l}\text { Efficiency business } \\
\text { model }\end{array}$} & $\begin{array}{l}\text { C1 We simplify the ways we deal with our transaction partners (suppliers, customers, } \\
\text { other participants, etc.) }\end{array}$ \\
\hline & $\begin{array}{l}\text { C2 Communication cost and information processing cost during the transaction have } \\
\text { been significantly reduced. }\end{array}$ \\
\hline & C3 Transaction partners can get and grasp the transaction information in time. \\
\hline & $\begin{array}{l}\text { C4 Our business model is not perfect, the efficiency of daily transaction needs to be } \\
\text { improved (reverse) }\end{array}$ \\
\hline & $\begin{array}{l}\text { C5 In the course of company's operation, we often share information with external } \\
\text { participants. }\end{array}$ \\
\hline \multicolumn{2}{|c|}{$\begin{array}{l}\text { Please rate the level of your firm's involvement in each of the following practices during the last year. } \\
(1=\text { very low; } 5=\text { very high) }\end{array}$} \\
\hline \multirow{4}{*}{ Firm performance } & D1 Customers are very satisfied with our products (services). \\
\hline & D2 We can provide customers with their expected value. \\
\hline & D3 We are able to maintain existing customers. \\
\hline & D4 We get the expected market share. \\
\hline
\end{tabular}

\section{References}

1. WWF. Living Planet Report. World Wide Fund for Nature. Available online: http://wwf.panda.org/about_ our_earth/all_publications/living_planet_report/2012_lpr / (accessed on 26 June 2017).

2. Aragón-Correa, J.A.; Hurtado-Torres, N.; Sharma, S. Environmental strategy and performance in small firms: A resource-based perspective. J. Environ. Manag. 2008, 86, 88-103. [CrossRef] [PubMed] 
3. Horbach, J.; Rammer, C.; Rennings, K. Determinants of eco-innovation by types of environmental impact: The role of regulatory push/pull, technology push or market pull. Ecol. Econ. 2012, 78, 112-122. [CrossRef]

4. Berrone, P.; Fosfuri, A.; Gelabert, L.; Gomez-Mejia, L. Necessity as the mother of green inventions: Institutional pressures and environmental innovations. Strateg. Manag. J. 2013, 34, 891-909. [CrossRef]

5. Amores-Salvadó, J.; Castro, M.; Navas-lópez, J. Green corporate image: Moderating the connection between environmental product innovation and firm performance. J. Clean. Prod. 2014, 83, 356-365. [CrossRef]

6. Rexhäuser, S.; Rammer, C. Environmental innovations and firm profitability: Unmasking the Porter hypothesis. Environ. Resour. Econ. 2014, 57, 145-167. [CrossRef]

7. Ghisetti, C.; Rennings, K. Environmental innovations and profitability: How does it pay to be green? An empirical analysis on the German innovation survey. J. Clean. Prod. 2014, 75, 106-117. [CrossRef]

8. Wagner, M. The link of environmental and economic performance: Drivers and limitations of sustainability integration. J. Bus. Res. 2015, 68, 1306-1317. [CrossRef]

9. Ma, Y.; Hou, G.S.; Xin, B.G. Green process innovation and innovation benefit: The mediating effect of firm image. Sustainability 2017, 9, 1778.

10. Aschehoug, S.H.; Boks, C.; Støren, S. Environmental information from stakeholders supporting product development. J. Clean. Prod. 2012, 31,1-13. [CrossRef]

11. Marchi, V.; Grandinetti, R. Knowledge strategies for environmental innovations: The case of Italian manufacturing firms. J. Knowl. Manag. 2013, 17, 569-582. [CrossRef]

12. Chang, C. The determinants of green product innovation performance. Corp. Soc. Responsib. Environ. Manag. 2016, 23, 65-76. [CrossRef]

13. Delmas, M.A.; Pekovic, S. Organizational configurations for sustainability and employee productivity: A qualitative comparative analysis approach. Bus. Soc. 2018, 57, 216-251. [CrossRef]

14. Baker, W.E.; Sinkula, J.M. Environmental marketing strategy and firm performance: Effects on new product performance and market share. J. Acad. Mark. Sci. 2005, 33, 461-475. [CrossRef]

15. Dangelico, R.M.; Pontrandolfo, P. Being 'green and competitive': The impact of environmental actions and collaborations on firm performance. Bus. Strategy Environ. 2015, 24, 413-430. [CrossRef]

16. Walker, K.; Ni, N.; Dyck, B. Recipes for successful sustainability: Empirical organizational configurations for strong corporate environmental performance. Bus. Strategy Environ. 2015, 24, 40-57. [CrossRef]

17. Bolton, D.; Landells, T. Reconceptualizing power relations as sustainable business practice. Bus. Strategy Environ. 2015, 24, 604-616. [CrossRef]

18. Zollo, M.; Cennamo, C.; Neumann, K. Beyond what and why: Understanding organizational evolution towards sustainable enterprise models. Organ. Environ. 2013, 26, 241-259. [CrossRef]

19. Provasnek, A.K.; Schmid, E.; Geissler, B. Sustainable corporate entrepreneurship: Performance and strategies toward innovation. Bus. Strategy Environ. 2017, 26, 521-535. [CrossRef]

20. Demirel, P.; Kesidou, E. Stimulating different types of eco-innovation in the UK: Government policies and firm motivations. Ecol. Econ. 2011, 70, 1546-1557. [CrossRef]

21. Lüdeke-Freund, F.; Dembek, K. Sustainable business model research and practice: Emerging field or passing fancy? J. Clean. Prod. 2017, 168, 1668-1678. [CrossRef]

22. De Medeiros, J.F.; Ribeiro, J.L.D.; Cortimiglia, M.N. Success factors for environmentally sustainable product innovation: A systematic literature review. J. Clean. Prod. 2014, 65, 76-86. [CrossRef]

23. Pujari, D. Eco-innovation and new product development: Understanding the influences on market performance. Technovation 2006, 26, 76-85. [CrossRef]

24. Dangelico, R.M. Green product innovation: Where we are and where we are going. Bus. Strategy Environ. 2016, 25, 560-576. [CrossRef]

25. Kuratko, D.F.; Morris, M.H.; Schindehutte, M. Understanding the dynamics of entrepreneurship through framework approaches. Small Bus. Econ. 2015, 45, 1-13. [CrossRef]

26. Schaltegger, S.; Wagner, M. Sustainable entrepreneurship and sustainability innovation: Categories and interactions. Bus. Strategy Environ. 2011, 20, 222-237. [CrossRef]

27. Chesbrough, H.; Crowther, A.K. Beyond high tech: Early adopters of open innovation in other industries. RD Manag. 2006, 36, 229-236. [CrossRef]

28. Triguero, A.; Moreno-Mondéjar, L.; Davia, M.A. Drivers of different types of eco-innovation in European SMEs. Ecol. Econ. 2013, 92, 25-33. [CrossRef] 
29. Boons, F.; Montalvo, C.; Quist, J. Sustainable innovation, business models and economic performance: An overview. J. Clean. Prod. 2013, 45, 1-8. [CrossRef]

30. Doganova, L.; Renault, M. What do business models do? Innovation devices in technology entrepreneurship. Res. Policy 2009, 38, 1559-1570. [CrossRef]

31. McKinsey \& Company. How Companies Think about Climate Change: A McKinsey Global Survey. The McKinsey Quarterly, 17 February 2008.

32. Ambec, S.; Lanoie, P. Does it pay to be green? A systematic overview. Acad. Manag. Perspect. 2008, $22,45-62$.

33. Del, R.; Gonzalez, P. The empirical analysis of the determinants for environmental technological change: A research agenda. Ecol. Econ. 2009, 68, 861-878.

34. Sharma, S.; Henriques, I. Stakeholder influences on sustainability practices in the Canadian forest products industry. Strateg. Manag. J. 2005, 26, 159-180. [CrossRef]

35. Weng, H.H.R.; Chen, J.S.; Chen, P.C. Effects of green innovation on environmental and corporate performance: A stakeholder perspective. Sustainability 2015, 7, 4997-5026. [CrossRef]

36. Delmas, M.A.; Toffel, M.W. Organizational responses to environmental demands: Opending the black box. Strateg. Manag. J. 2008, 29, 1027-1055. [CrossRef]

37. Zott, C.; Amit, R. The fit between product market strategy and business model: Implications for firm performance. Strateg. Manag. J. 2008, 29, 1-26. [CrossRef]

38. Zott, C.; Amit, R.; Massa, L. The business model: Recent developments and future research. J. Manag. 2011, 37, 1019-1042.

39. Magretta, J. Why business models matter. Havard Bus. Rev. 2002, 5, 86-92.

40. Wei, Z.; Yang, D.; Sun, B. The fit between technological innovation and business model design for firm growth: Evidence from China. RD Manag. 2014, 44, 288-305. [CrossRef]

41. Teece, D.J. Business models, business strategy and innovation. Long Range Plan. 2010, 43, 172-194. [CrossRef]

42. Mitchell, D.; Coles, C. The ultimate competitive advantage of continuing business model innovation. J. Bus. Strategy 2003, 24, 15-21. [CrossRef]

43. Brettel, M.; Strese, S.; Flatten, T.C. Improving the performance of business models with relationship marketing efforts: An entrepreneurial perspective. Eur. Manag. J. 2012, 30, 85-98. [CrossRef]

44. Podsakoff, P.M.; Organ, D.W. Self-reports in organizational research: Problems and prospects. J. Manag. 1986, 12, 531-544. [CrossRef]

45. Gay, L.R. Educational Research Competencies for Analysis and Application; Macmillan: New York, NY, USA, 1992.

46. Aiken, L.S.; West, S.G. Multiple Regression: Testing and Interpreting Interactions; Sage: Thousand Oaks, CA, USA, 1991.

47. Nirmalya, K.; Scheer, L.; Kotler, P. From market driven to market driving. Eur. Manag. J. 2000, 2, $129-142$.

48. Ottman, J.A.; Stafford, E.R.; Hartman, C.L. Avoiding green marketing myopia: Ways to improve consumer appeal for environmentally preferable products. Environ. Sci. Policy Sustain. Dev. 2006, 48, 22-36. [CrossRef]

49. Roper, A.S.W. Green Gauge Report 2002; Roper ASW: New York, NY, USA, 2002.

50. Gleim, M.R.; Smith, J.S.; Andrews, D. Against the green: A multi-method examination of the barriers to green consumption. J. Retail. 2013, 89, 44-61. [CrossRef]

51. Rex, E.; Baumann, H. Beyond ecolabels: What green marketing can learn from conventional marketing. J. Clean. Prod. 2007, 15, 567-576. [CrossRef]

52. Wong, C.W.Y.; Lai, K.; Shang, K.C. Green operations and the moderating role of environmental management capability of suppliers on manufacturing firm performance. Int. J. Prod. Econ. 2012, 140, 283-294. [CrossRef]

53. Zott, C.; Amit, R. Business model design and the performance of entrepreneurial firms. Organ. Sci. 2007, 18, 181-199. [CrossRef]

54. Chiffoleau, Y. Learning about innovation through networks: The development of environmental-friendly viticulture. Technovation 2005, 25, 1193-1204. [CrossRef]

55. Garcia-Castro, R.; Aguilera, R.V. Incremental value creation and appropriation in a world with multiple stakeholders. Strateg. Manag. J. 2015, 36, 137-147. [CrossRef]

(C) 2018 by the authors. Licensee MDPI, Basel, Switzerland. This article is an open access article distributed under the terms and conditions of the Creative Commons Attribution (CC BY) license (http:/ / creativecommons.org/licenses/by/4.0/). 